\title{
ATTITUDES TO EDUCATION REFLECTED IN THE CONTEXT OF THE US COLLEGE ADMISSIONS SCANDAL
}

In the early months of 2019, the internet was swarming with articles reporting on what became tagged as the US College Admissions Scandal. The media coverage focused on publicly exposed entertainment and business moguls who were involved in bribing several formally accredited higher education facilities in the US to ensure matriculation for their children; matriculation was based on financial endowments rather than academic merit. The specifics of the scandal gravitate toward a few curious characteristics: those who received the most media exposure were rich, mostly women (e.g. Lori Loughlin and Felicity Huffman) and, in most cases, their daughters. ${ }^{1}$ The universities involved in the scandal were many, among them, also those traditionally classified as prestigious or listed as Ivy League schools (e.g. Stanford, Harvard, Yale). These events and the related coverage spurred several questions, warranting interest in investigation of past and current attitudes toward formal education, their relevance in contemporary gender-roles, as compared to some of the historically noted practices in the United States.

\section{2}

\section{METHODS AND RESEARCH QUESTIONS}

The article relates a selection of available statistical data to the current attitudes to education. It compares the findings to the practices recorded in American history and investigates how these might feature in contemporary contexts. The research methods employed span several different approaches, focusing on collecting qualitative information as well as quantitative data. In the initial phase, the relevant qualitative information on the history of education in the US was compiled, namely, through a number of online and other documents. ${ }^{2}$

1 According to the list of sons and daughters implicated in the scandal, the ratio was 20 daughters to 11 sons (cf. Wikipedia source listed in the references), meaning that the ratio was close to $2: 1$ in favor of daughters.

2 As most of the historical content included here is subject to encyclopedia knowledge, these concepts were researched through a few print and several general content online resources, such as those listed in References under US History (a), US History (b), Republican Motherhood, Harvard Education, and similar sources (see the list of references). 
The following research phase focused on accruing quantitative statistical data, which was subsequently used in relevant calculations. The figures and the findings were then interpreted within the context of the recent US College Admissions Scandal, with the purpose of unveiling the assumed shift in attitudes toward acquiring formal academic credentials in the US and providing a brief comparison to related Slovenian figures.

The research is aimed at answering the questions of whether the view of the increasing value of education and academic credentials is supported by historical data on educational practices within the US, and whether the recent event known as the US College Admissions Scandal implies a major shift in attitudes within the US toward formally accredited education.

\section{3}

\section{A BRIEF HISTORICAL OVERVIEW OF EDUCATIONAL POLICIES} IN THE US

When it comes to education, the US boasts a long tradition. In the years following their formal independence from the British Crown in 1776, the US was considered one of the most progressive states in the world, including in its attitude toward education. The first American schools date as far back as 1635, when the oldest existing school in the US - Boston Latin School - was founded as the first public school. The interpretation of public in its description was that of being accessible to all, which did not entail being taxpayer-supported; this runs counter to how the classification of public is commonly understood in most contemporary contexts (with exceptions such as Great Britain, for instance).

In the early decades of the $17^{\text {th }}$ century, basic literacy and arithmetic skills were acquired within the family, assuming that the parents were able to teach those skills to their children. Language skills in particular were given prominence as these were recognized as practical in 'matters of daily life' (see quote below); these skills included those pertaining to communication, debate, preaching, access to scriptures (where Latin was in the forefront), as well as business and legal documents.

This certainly was one of the more important educational innovations in early America, for the concept of free schools was largely unknown in civilized Europe in that age. The subjects taught were designed to assist students in practical matters of daily life: arithmetic for business; languages to communicate, debate, and preach; and reading to provide access to the Bible and to understand contracts, government documents, and laws. ${ }^{3}$ 
Literacy levels varied according to the region. In New England, which belonged to the northernmost group of colonies, the literacy levels were the highest, due to its involvement in the Protestant Reformation, where its primary purpose was being able to read the Scriptures. According to Aebi (online source), the Bible was a powerful force in education in the $17^{\text {th }}$ and $18^{\text {th }}$ centuries, and this contributed to the levels of literacy in America exceeding those of European nations.

The King James Version of the Bible and some earlier versions were brought to America by Puritans, Presbyterians, and others. Every family tried to have one, and they valued schooling because they needed it to read their Bibles, so the colonists became more literate than the Europeans. (ibid.)

In some other regions, such as the South, for instance, this was not the case. The Anglican Church was the established church, while the class distinctions between the wealthier planters and the working class indentured servants did not support the idea of publicly accessible education for all. Instead, the former, the planters, would opt for private tutors for their children or send them to prestigious educational facilities back in the Old World, in England. The members of the latter of the two social classes, the working class, however, were expected to remain uneducated.

In the subsequent decades and centuries, up until the $19^{\text {th }}$ century, the role of schools in New England developed to the extent that they were able to take over educational responsibilities which had traditionally been handled by parents. This marked an essential milestone in providing access to education and presenting a model practice, particularly in the light of the concept of a City upon a Hill, where Americans were being perceived as a model nation, enjoying its reputation of exceptionalism.

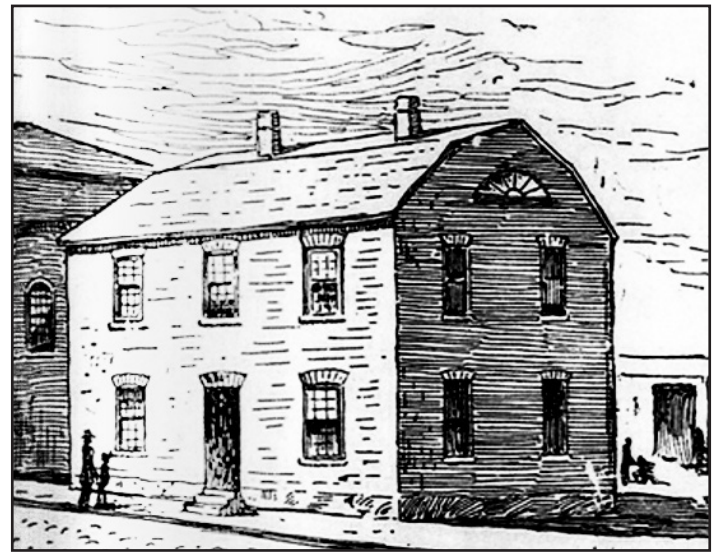

Picture 1: source: Leonard 2020 
The New England colonies were among the first within the US to introduce a requirement that towns should set up schools (for instance, in Boston, New York, Philadelphia, to name a few). Children were supposed to get a proper education, which implied its compulsory status. The other New England colonies followed suit, as did the Middle and Southern colonies, albeit not until a few years or even decades later. The schools were all male and all white. Only a few facilities were available for girls. It wasn't until the $18^{\text {th }}$ century that common one-room schools were established; these charged the families rate bills, which corresponds to today's tuition.

We can thus arrive at the conclusion that in the US, in the past, schools and education in general were in high regard, closely connected to religion, and predominately intended to train men into ministers. Literacy was, in principle, motivated by the idea that people, with a primary focus on men, should be able to read the Bible. At first, the importance of learning Latin was closely connected with being able to read the Bible, but soon translations into English were available and became widely accessible with the invention of the printing press. The Bible was translated into the local vernaculars, such as Algonquian, for instance, which indicates the significance as well as the favorable attitudes toward the development of (foreign) language skills - primarily focusing on reading, elocution and orthography - and increasing educational levels in general.

Within this context, as far back as 1636, Harvard College was founded, with its primary focus on preparing young men for ministry, the many of whom subsequently turned a different corner - the one leading to law, medicine, government or business. Yale, another representative of the oldest educational institutions in the US, was founded by Puritans in 1701, in response to the more liberal theology that was taught at Harvard. They wanted to train more orthodox ministers. These two and others eventually became known around the world as prestigious American higher education facilities, traditionally often referred to as Ivy League Colleges. In addition to Harvard and Yale, belonging to this group are also Princeton, Brown, Dartmouth, Columbia, Cornell, and Pennsylvania.

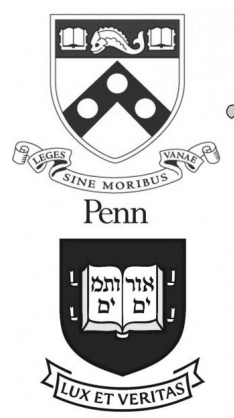

Yale
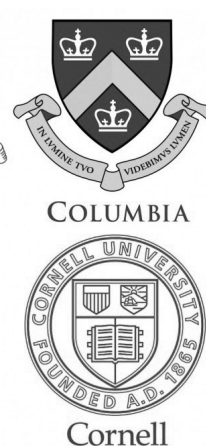

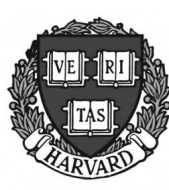

HARVARD

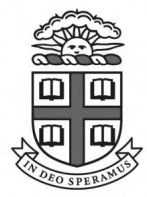

BROWN

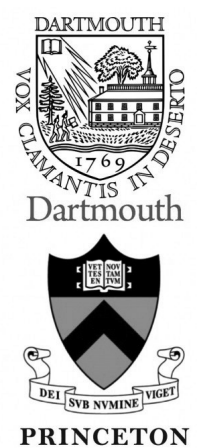

PRINCETON

Picture 2: List of the US Ivy League colleges; adapted from Kennedy 2019, source: Shatorch.com 
Within the American cultural context, heavily characterized by the settlers' ethnic and linguistic diversity, language has played a prominent role in the formation of the new nation, since it is one of the basic ingredients any country or nation needs in order to attain important aspects of sovereignty and independence (in addition to a common and sovereign geographical area, a common set of values, folklore and history; cf. Burazer 2020, chapter 3.5).

\subsection{The concept of Republican Motherhood}

So far, we have seen that in $17^{\text {th }}$-century America, education was not taken for granted. On the contrary, it was taken seriously as quite early on the need for public education arose and with it the expectation of providing the citizens with knowledge so as to develop a model nation. As the number of formal education facilities was on the rise, and with it their discriminatory policies, social, racial and gender disparities began to surface, since schools were predominantly white, male and mostly the prerogative of those who could afford tuition fees.

In families where attending formal education was not an option, the role of women was considered as a valuable contribution to state and family matters. Women were thought to be best suited for the role of guiding and teaching children. This concept was later translated into the so-called Republican Motherhood. ${ }^{4}$ Women writers, such as Sedgwick, Child and Sigourney (cf. Robbins 2002), were respected role models and advocates for improving and expanding education for females. These important activities fostering greater educational access triggered the process of strengthening the position of women as educators and supervisors of American moral and ethical values. This meant that the core subjects of all male schools, such as math and sciences and the like, had to be supplemented by arts and humanities subjects, including languages. Their role in education was considered to be one of nation building and thus extremely important, which meant it enjoyed abundant public support. This also led to ample financial endowments and consequently establishment of all-female academies. The rich planters were particularly determined to have their daughters schooled as education often served as a substitute for a dowry in marriage arrangements. The process of passing and subsequently enforcing the laws on compulsory education was one that spanned over several decades and centuries even, but eventually the laws were passed in all of the US states. As a result, roughly one hundred years ago, all American children were required to stay in school at least until the age of 14 .

$4 \quad$ Several encyclopedia-type sources provide additional information on this concept (see the reference under Presidency of Franklin D. Roosevelt). 


\subsection{The overall effect of accessibility of college education}

These important state-level education-related legal provisions were the basis for several subsequent beneficial effects at the national level that are still relevant today. Acquiring college-level education ensured many young men a smooth transition from rural farms to complex urban areas. It also promoted upward social mobility (except for the more elite colleges, which became increasingly exclusive and contributed relatively little to it, while assuming an important role in the formation of a Northeastern elite with great power).

The years prior to WW2 witnessed the great Depression when the situation relating to economy in the US was plummeting. ${ }^{5}$ The elitist facilities were hit by hostility from the government, as the state-budget-funded facilities were losing financial support, resulting in teachers' salaries being withheld. This was reflected in Roosevelt's The New Deal, where anti-elitist policies were put forward in defense of publicly accessible education for all, though these have been severely criticized for having taken the matter too far (cf. Leuchtenburg; online source):

The New Deal approach to education was a radical departure from educational best practices. It was specifically designed for the poor and staffed largely by women on relief. It was not based on professionalism, nor was it designed by experts. Instead it was premised on the anti-elitist notion that a good teacher does not need paper credentials, that learning does not need a formal classroom and that the highest priority should go to the bottom tier of society. (ibid.)

\subsection{The growth of human capital}

The growth of human capital was the next important goal that the US pursued in their educational policies. In comparison to Europe, the commitment to expand education past age 14 ensured an advantage over Europe for much of the $20^{\text {th }}$ century, as they were pursuing the goal of educating citizens, which was also aimed at improving citizenship, developing higher-order cognitive traits, and producing the managerial and professional leadership needed for rapid economic modernization. By 1940, 50\% of Americans had finished secondary education/high school. This was by far on a much higher level compared to Europe at the time.

The wealthiest European nations, such as Germany and Britain, had far more exclusivity in their education system; few youths attended past age 14. Apart from technical training schools, European secondary schooling was dominated by children of the wealthy and the social elites. (source: Wikipedia on History of education in the US)

$5 \quad$ Cf. Britannica article on Great Depression. 
According to Moulton (1963, pp. 82-83), it was around that time that foreign languages within American schools came to the fore in the educational circles. In the decades preceding the $1940 \mathrm{~s}$, in the 1920s and the 1930s, the US was experiencing a linguistic isolationism of sorts, as foreign language study in the US was characterized by three major factors:

- there was relatively little foreign language instruction in schools, and it was often short - not more than 2 years

- the choice was limited to very few languages - Latin, Spanish or French in high school; in college German and Greek were added to this selection

- the type of instruction used was the grammar-translation method, focused predominantly on explaining grammar.

After the Pearl Harbor attack in 1941, linguistic isolationism came to an end. With the dimensions of the Second World War reaching across continents and thus across a host of different cultures and languages, the military as well as the government officials recognized the importance of learning foreign languages for communicative purposes. Consequently, the focus in foreign language instruction methodology shifted from grammar-translation to practical speaking knowledge (ibid., p. 84).

The decade that followed was marked by a major transformation of American education, with specific focus on improving organization, increasing funding and achieving a higher level of standardization across the country, starting with private institutions and eventually filtering down to public schools. ${ }^{6}$

\subsection{A Nation at Risk}

Fast forward from the post-Second-World-War era to the 1980s: the US National Commission on Excellence in Education released a report titled A Nation at Risk (1983; governmental online source). Soon afterward, American conservatives were calling for an increase in academic rigor, including an increase in the number of school days per year, longer school days and higher testing standards. English scholar E.D. Hirsch (in Edwards 2009) made an attack on progressive education, advocating an emphasis on 'cultural literacy' - the facts, phrases, and texts that Hirsch asserted are essential for decoding basic texts and maintaining communication (ibid.).

Hirsch particularly underlines the importance of language processing skills in establishing "broad knowledge in early education due to the overwhelming importance of reading" (ibid.). He sees decoding words as a necessary part of reading and emphasizes that "unlike speech, it will not happen naturally." In his view, there is a deep interconnectedness between cultural literacy and successful general literacy, "because authors

6 Online source: https:/www.encyclopedia.com/social-sciences/culture-magazines/1940s-education-overview 
assume their readers have command of a certain body of knowledge." He also draws attention to the relevant differences between speaking and reading skills, where the former do not automatically endorse the latter.

In educational circles, however, the main criticism directed at Hirsch's proposals is based in the "claims regarding an 'information explosion' that makes attempts to anticipate future information requirements impossible," and consequently diverts attention to 'process' and 'processes' [as] the highest form of content [where] 'critical thinking skills' and a 'love of learning' are seen as primary intellectual tools, while "avocation of fixed knowledge is sexist, fundamentalist and racist" (ibid.).

Based on the ideas and arguments presented above, we can see that even if Hirsch's ideas might enjoy approval in popular circles, the same is not true for educational circles. With his arguments targeted at American education having been "undermined by a deep contempt for factual knowledge and an addiction to Romantic fallacies such as 'project method' instruction, 'child/student-centered' learning, artificial 'self-esteem' building, and "critical thinking skills' transmission theory," he seems to be closer to certain educational practices in countries outside the US, which persist in more traditional educational methods, by placing emphasis on "mastery of broad and specific academic knowledge and do not shy away from memorization, practice, and drill" (ibid.). Hirsch's ideas, however, remain influential in conservative circles within the US, but maintain a level of controversy because, as Edwards argues:

Opponents from the political left generally accuse Hirsch of elitism. Worse yet in their minds, Hirsch's assertion might lead to a rejection of toleration, pluralism, and relativism. On the political right, Hirsch has been assailed as totalitarian, for his idea lends itself to turning over curriculum selection to federal authorities and thereby eliminating the time-honored American tradition of locally controlled schools. (Edwards 2009)

\subsection{No Child Left Behind}

By 1990, the United States spent 2 percent of its budget on education, compared with 30 percent on support for the elderly (Roser and Ortiz Ospina 2016). It was imperative that something be done to remedy the situation. In consequence, a major national law was passed by a bipartisan coalition in Congress in 2002, No Child Left Behind, which marked a new direction. In exchange for more federal aid, the states were required to measure progress and punish schools that were not meeting the goals as measured by standardized state exams in math and language skills (Duignan 2001).

Given that the United States does not list one single language as the official language at the federal level, and given its distinct linguistic diversity with Native Americans and 
the immigrants to the New World, language became a key issue in discussions on implementation of the policy's provisions regarding testing. The major feature of the issue was state refusal to produce non-English versions of the tests, even though, legally, Native American students, for instance, could be tested in their native language. This opened another distinctive and unique issue within the American educational realm.

While the No Child Left Behind policy did not yield the expected long-term results, it did spur several changes in the educational practices, many of which are not considered a marked progress - such as a number of states dropping from the curriculum the requirement to teach cursive writing or starting the school day by singing the national anthem, as was once done. Few schools now have mandatory arts class, and few schools have mandatory recess for children, which educators are fervently trying to reinstate.

As much as early American efforts to provide and maintain access to education for all citizens and thus ensure the building of a nation that would represent a model for the rest of the world was a step toward equal opportunities taken in good faith, this brief historical overview reveals that certain educational policies introduced at national level did not support these efforts. If anything, they in a way kept the focus on elitist facilities, accessible mostly to those with considerable means and of exclusive social standing, while in other areas of public education certain policies that were being implemented might have contributed to a lowering of educational standards.

For the purposes of the present investigation, we have looked at the proportions of available educational institutions per citizen and percentages of citizens who have completed secondary and higher level of education in the US and compared them to those in Slovenia. The comparison might serve as an indicator of the share of citizens motivated to reach expected higher educational standards. According to the following figures, retrieved from the official US Department of Education website, in fall 2017, ${ }^{7}$ there were 4,298 institutions of higher education in the US, a representative of a large nation, of which 1,626 were public colleges, 1,687 were private nonprofit schools, and 985 were for-profit schools. The data is comprehensive and divides the institutions into categories such as four-year colleges and universities and two-year schools, often known as community colleges, all of which are included in the count (cf. Table 1 below).

The numbers for Slovenia, representative of a small nation compared to the US, at first sight paint a somewhat different picture, as they are considerably lower. According to the Slovenian education website (cf. also the listed online sources ${ }^{8}$ ), there are only 5 public

7 CCD (Common Core of Data) retrieved from NCES (National Center for Education Statistics) on American public schools (see the list of references)

8 Slovenia Education website list of higher education institutions (see the list of references) 
institutions of higher education and 25 private, in addition to 5 formally accredited private institutions (Pajnič 2011: 19-39; for more specific information, see the list in the online source, cf. footnote 8). In order to discern whether there are quantitative differences in accessibility of educational institutions to the citizens of both states, the US and Slovenia, we have calculated the ratio of citizens per institution at the US federal level, which amounted to just below 200,000 per public college, or approximately 75,000 per any college. In Slovenia, that ratio is approximately 400,000 per public university, or just over 65,000 per any college (see Table 1 below). What these calculated ratios indicate is that the US in fact boasts a higher level of accessibility of higher education institutions than Slovenia.

\begin{tabular}{|l|l|l|}
\hline \multicolumn{1}{|c|}{$\begin{array}{l}\text { population } \\
\text { higher ed. } \\
\text { institutions }\end{array}$} & $\begin{array}{l}\text { the US } \\
\text { (population 327,2 mil.) }\end{array}$ & $\begin{array}{l}\text { Slovenia } \\
\text { (population 2,06 mil.) }\end{array}$ \\
\hline public & 1,626 & 5 \\
\hline private & 2,672 (for and no-profit) & 25 \\
\hline total & $\mathbf{4 , 2 9 8}$ & $\mathbf{3 0}$ \\
\hline ratio: $\mathbf{N}^{\circ}$ of citizens / & $200.000 /$ public & $400,000 /$ public \\
per institution & $75,000 /$ private & $\begin{array}{l}65,000 / \text { private } \\
68,000 / \text { total }\end{array}$ \\
\hline
\end{tabular}

Table 1: The current ratio of higher education institutions per citizen in the US and Slovenia

The numbers pertaining to the level of education achieved by citizens of the two countries also point in the direction of the US being slightly more successful in having its citizens stay in school until they finish high school, at least. According to the Digest of Education Statistics, ${ }^{9}$ in the United States, there were over 92\% high school graduates in 2018 in the age group 25-34, with the number being on the increase from $88.2 \%$ in 2000 . According to the same source, the numbers for Slovenia are slightly lower in comparison to 2000 , but on a solid upward curve, having gone from $85.4 \%$ of high school graduates in the 25-34 age group in 2000 to $94.3 \%$ in 2018, thus marking a greater progress in comparison with figures for the US.

9 Digest of Education Statistics (see the list of references) 


\begin{tabular}{|l|l|l|l|}
\hline \multicolumn{1}{|r|}{ \%ear/country } & in year & the US & Slovenia \\
\hline completed higher education & & & \\
\hline \multirow{2}{*}{ completed high school } & 2000 & 38.1 & 19.3 \\
\cline { 2 - 5 } & 2018 & 49.8 & 40.7 \\
\hline & 2000 & 88.2 & 84.4 \\
\cline { 2 - 5 } & 2018 & 92.4 & 94.3 \\
\hline
\end{tabular}

Table 2: Percentages of high school and higher education graduates in the US and Slovenia in the 25-34 age-group (Source: Digest of Education Statistics)

Of the world countries included in the statistics (ibid.), a steady increase in inclusion in education process has been marked in most other countries featured in the survey, besides the US and Slovenia (such as Australia, Columbia, Mexico, to name a few), while a few have recorded an actual drop (Slovak Republic, for instance, marked a drop in the same age group from $93.7 \%$ in year 2000 to $91.9 \%$ in 2018).

In the decades preceding the turn of the millennium, the numbers for the US high school graduation rates have gone up from $50.5 \%$ in the $1940 \mathrm{~s}$, peaking at $77 \%$ in 1969 , dropping to $69 \%$ with the class of 2007 , and then resuming on the upward curve ${ }^{10}$ And according to Gabrič (2000; cf. Table 3 below), Slovenia follows the same pattern as the statistics for inclusion in the education process has been on a steady upward curve over the past $60+$ years, with significant growth in the number of students and graduates of institutes of higher education (Gabrič 2000; cf. table 4 below)

\begin{tabular}{|l|l|l|l|}
\hline \multicolumn{1}{|c|}{ year } & 1953 & 1961 & 1971 \\
\% of... & 90.9 & 99.7 & 100.0 \\
\hline $\begin{array}{l}\text { children aged 7-14 } \\
\text { attending primary school }\end{array}$ & 20.4 & 28.9 & 43.4 \\
\hline $\begin{array}{l}\text { young people aged 15-19 } \\
\text { attending secondary school }\end{array}$ & 2.7 & 5.4 & 8.9 \\
\hline $\begin{array}{l}\text { young people aged 20-24 } \\
\text { studying at university }\end{array}$ & 2.9 & \\
\hline
\end{tabular}

Table 3: Percentages of children and the young included in the education process in Slovenia; source: Gabrič 2000 


\begin{tabular}{|l|l|l|}
\hline \multicolumn{1}{|l|}{$\begin{array}{r}\text { No. of } \\
\text { Year }\end{array}$} & students & graduates \\
\hline $\mathbf{1 9 4 6 / 4 7}$ & 3,479 & 69 \\
\hline $\mathbf{1 9 5 6 / 5 7}$ & 7,203 & 846 \\
\hline $\mathbf{1 9 6 6 / 6 7}$ & 15,085 & 2,975 \\
\hline $\mathbf{1 9 7 6 / 7 7}$ & 29,279 & 4,845 \\
\hline $\mathbf{1 9 8 6 / 8 7}$ & 30,985 & 5,534 \\
\hline
\end{tabular}

Table 4: The number of students and graduates of Slovenia's institutes of tertiary education; source: Gabrič 2000

\section{IMPLICATIONS FOR ATTITUDES TOWARD HIGHER EDUCATION - DISCUSSION}

The historical overview and comparison with recent data show that active participation in education at all levels has been increasingly on the rise, not only in the US but in many - if not most - countries around the world, according to the numbers published in Digest of Education Statistics. What the above figures suggest (cf. Tables 3 and 4) is that the increase in interest and active participation in the education process is an indication of the growing value of education. On the other hand, the reported abuse of academic credentials and accompanying commentary (cf. MacDonald 2019a and 2019b) imply a somewhat distorted perception of the status of formal academic qualifications.

The question arises as to whether the growth marked in numbers and percentages of inclusion in education is in fact needs- and motivation-driven and whether it reflects a rise in academic achievement at national levels. In the opinion of some of the investigative journalists who provided media coverage of the US College Admissions Scandal (e.g. MacDonald 2019a and 2019b, Friedman 2019), this might not be the case. In the words of MacDonald, college has become "Primarily [...] about accrediting its graduates and signaling $[\ldots]$ their value to future employers as responsible workers" (2019a). The implication is that these trends in higher education credentials earned on legacy or other formally unacceptable preferences, rather than academic merit, reveal a significant deviation from the traditional perception of higher education, thus generating distrust and somewhat negative attitudes toward academic credentials, resulting in diminishing their value.

Such academic practices might well be taking us back to regarding (higher or any other formal) education as a sign of wealth and power, of the status which places one above the law, or even pushing us as far back in history as the point in time when formal education was considered a form of dowry. But who or what is really on trial in this scandal? According to MacDonald, most of the blame falls on the institutions of higher education themselves, on the grounds of failing to create an environment which nurtures 
values such as honesty, high level work ethics, a high-demand approach to teaching, and the like. Instead, the recent scandal reveals an affinity toward allowing star campus residents to project the image of college-life akin to that of entertainment business or social-media celebrity lifestyle.

None of this could have happened if higher education had not itself become a corrupt institution, featuring low classroom demands, no core knowledge acquisition, low grading standards, fashionable (but society-destroying) left-wing activism, luxury-hotel amenities, endless partying, and huge expense. Students often learn virtually nothing during their college years [...]. (MacDonald 2019b)

This seems to result in another significant deviation, particularly in reference to the concept of republican motherhood discussed above, where historically the strength of the matriarchs was reflected in a take-charge type of attitude, which requires a sizeable investment of time and effort, rather than a display of material or financial resources, to ensure their children's academic advancements by transmitting knowledge from parents to children. By replacing this traditional parental role with one of exerting power over those who lack the resources to stand their ground (reference here is to those students who would have been accepted to a university on academic merit, had they not been denied access on account of such dishonest practices), those involved in the scandal did not acknowledge the accomplishments of generations who struggled to achieve equality of opportunity, ${ }^{11}$ part of which is believed to be set in access to knowledge and prospects of achieving academic excellence.

\section{6} CONCLUSION

The results of the investigation show that an historical overview of educational practices in the US supports the view of the increasing value of academic credentials, despite the recently exposed admissions scandal. However powerfully this event might have reflected on the direction of academic credentials being undermined, the legal ramifications awaiting those involved assure us that this is not the case.

A contemporary stance on states and societies providing access to (formal) education to all citizens in a non-discriminatory manner should be the standard observed and mission pursued by any institution of higher education. On the other hand, it is also important to "expose the myth that a college credential is the prerequisite to a productive, fulfilling life" (MacDonald 2019b). An historic overview of the path that the development of (higher) educational facilities and practices has had to tread in order to grow

11 For a more comprehensive discussion of American values and attitudes cf. Burazer 2020, specifically Part 3, pp. $55-59$. 
into an efficient system of passing on knowledge from one generation to the next is a testament to the level of investment in terms of time and effort into this interminable mission. It is unacceptable to downgrade its value by allowing its beneficiaries to treat it like a commodity, whose price is driven by forces operating beyond the law and beneath the expected standards of integrity. In the words of MacDonald (2019a), media coverage of the scandal focused around two major takeaways: "an elite college degree has taken on wildly inflated importance in American society, and the sports-industrial complex enjoys wildly inflated power within universities." We add to these the important aspect of uncovering a scheme which denied the mechanism of an equalizer such as knowledge and education to serve its purpose of preserving the traditional American value of equality of opportunity for all; instead, it turned this purpose into yet another de-equalizer, further deepening the social divide for those less fortunate.

\section{BIBLIOGRAPHY}

AEBI, Charles. Bible in American schools - 1700-1900. Online source. Retrieved from: https://barlowvincentchurchofchrist.com/hp_wordpress/wp-content/uploads/2012/04/ THE-BIBLE-USE-IN-AMERICAN-SCHOOLS-1700-1900.pdf. Accessed on 7th November 2020.

BURAZER, Lara (2020) Local Attitudes \& Global perspectives: re-examining (implicit) beliefs and attitudes - an approach to teaching (American) culture. Ljubljana: Ljubljana University Press, Faculty of Arts (Znanstvena založba Filozofske fakultete, UL).

DIGEST OF EDUCATION STATISTICS. Retrieved from: https://nces.ed.gov/programs/digest/d19/tables/dt19_603.10.asp ; accessed on October 15th 2020.

DUIGNAN, Brian (2001) No Child Left Behind. Retrieved from: https://www.britannica.com/topic/No-Child-Left-Behind-Act; accessed on September $20^{\text {th }} 2020$.

EDWARDS, Jason R. (2009) E.D. HIRSCH Jr.: The Twentieth Century's Liberal Conservative Educator. Online source. Retrieved from: https://www.faithandfreedom. com/e-d-hirsch-jr-the-twentieth-centurys-liberal-conservative-educator/; accessed on September $20^{\text {th }} 2020$.

ENCYCLOPEDIA. Online source, retrieved from: https://www.encyclopedia.com/education/news-and-education-magazines/education-1929-1941; accessed on October $18^{\text {th }} 2020$.

FRIEDMAN, Zack (2019) 30 Facts about the College Admissions Scandal. Online source. Retrieved from: https:/www.forbes.com/sites/zackfriedman/2019/03/18/30facts-college-admissions-scandal/\#5cf2cfc112a0; accessed on September $20^{\text {th }} 2020$.

GABRIČ, Aleš (2000) The education system in Slovenia in the $20^{\text {th }}$ century. Družboslovne razprave. FDV, DR, Vol. XVI 2000, pp. 32-33. Online source. Retrieved from: 
http://dk.fdv.uni-lj.si/druzboslovnerazprave/pdfs/dr32-33Gabric.pdf; accessed on September $20^{\text {th }} 2020$.

GOLDIN, Claudia/Lawrence F. KATZ (1999) The Shaping of Higher Education: The Formative Years in The United States, 1890-1940. Journal of Economic Perspectives 13, no. 1 (Winter): 37-62. doi:10.3386/h0119. Online source. Retrieved from: http://nrs. harvard.edu/urn-3:HUL.InstRepos:42662008, accessed on September $20^{\text {th }} 2020$.

GREAT DEPRESSION. Britannica, online source. Retrieved from: https:/www.britannica.com/event/Great-Depression/Economic-impact\#ref234457 ; accessed on $7^{\text {th }}$ November 2020.

HARVARD EDUCATION. Online source. Retrieved from: https://dash.harvard.edu/bitstream/handle/1/42662008/h0119.pdf?sequence=2; accessed on September $20^{\text {th }} 2020$.

HISTORY OF EDUCATION IN THE UNITED STATES. Online source. Retrieved from: http://hitchhikersgui.de/History_of_education_in_the_United_States; accessed on September $20^{\text {th }} 2020$.

KENNEDY, Quinn (2019) Ivy leagues are overrated. Online source. Retrieved from: https://shatorch.com/1572/editorials/ivy-leagues-are-overrated/; accessed on September $20^{\text {th }} 2020$.

LEUCHTENBURG, William E. Online source. Retrieved from: https://millercenter.org/ president/fdroosevelt/domestic-affairs; accessed on October $16^{\text {th }} 2020$

MACDONALD, Heather (2019a) Preening College Admissions Officers and Entitled Celebrities. Online source. Retrieved from: https://www.foxnews.com/opinion/preening-college-admissions-officers-and-entitled-celebrities-heres-why-the-whole-scandal-was-inevitable ; accessed on October $15^{\text {th }} 2020$.

MACDONALD, Heather (2019b) Unmasking the College-Admissions Fraud. Online source. Retrieved from. https://www.city-journal.org/college-admissions-cheatingscandal; accessed on September $20^{\text {th }} 2020$.

MOULTON, William G. (1963) Linguistics and language teaching in the United States (1940-1960). Trends in European and American linguistics (offprint). Princeton University, Princeton. Online source. retrieved from: https://files.eric.ed.gov/fulltext/ED038879.pdf; accessed on 6th November 2020.

NATION AT RISK. Online source. Retrieved from: https:/www2.ed.gov/pubs/NatAtRisk/risk.html ; accessed on October $16^{\text {th }} 2020$.

NCES - NATIONAL CENTER FOR EDUCATION STATISTICS (CCD - COMMON CORE OF DATA - AMERICAN PUBLIC SCHOOLS). Online source. Retrieved from: https://nces.ed.gov/ccd/drpagency.asp; accessed on September $20^{\text {th }} 2020$.

PAJNIČ, Neža (2011) Higher Education in Slovenia. Ministry of Higher Education, Science and Technology. Ljubljana: CMEPIUS.

PICTURE 1: LEONARD, Carl (2013) Now we know em. Cavalier Generation - born 1615-1647. Online source. Retrieved from: https://nowweknowem.wordpress. 
com/2013/04/23/today-in-1635-the-boston-latin-school-became-the-first-public-school-founded-in-the-united-states/; accessed on September $20^{\text {th }} 2020$.

PICTURE 2. Online source. Retrieved and adapted from: https://shatorch.com/1572/editorials/ivy-leagues-are-overrated/; accessed on September $20^{\text {th }} 2020$.

PRESIDENCY OF FRANKLIN D. ROOSEVELT. Online source. Retrieved from: https://www.worddisk.com/wiki/Presidency_of_Franklin_D._Roosevelt,_first_ and_second_terms $/$; accessed on September $20^{\text {th }} 2020$.

REPUBLICAN MOTHERHOOD. Online source. Retrieved from: https://study.com/ academy/lesson/republican-motherhood-definition-summary.html; accessed on September $20^{\text {th }} 2020$.

ROBBINS, Sarah (2002) The Future Good and Great of Our Land: Republican Mothers, Female Authors, and Domesticated Literacy in Antebellum New England. The New England Quarterly, vol. 75, no. 4, 2002, pp. 562-591. JSTOR, www.jstor.org/ stable/1559860; accessed on October 18th 2020.

ROSER, Max/Esteban ORTIZ-OSPINA (2016) Financing Education. Our world in data. Online source. Retrieved from: https://ourworldindata.org/financing-education; accessed on September $20^{\text {th }} 2020$

SLOVENIA EDUCATION. Online source. Retrieved from: https://www.sloveniaeducation.info/higher-education/list-of-higher-education-institutions.html ; accessed on September $20^{\text {th }} 2020$

THE 1940s EDUCATION OVERVIEW. Online source. Retrieved from: https://www. encyclopedia.com/social-sciences/culture-magazines/1940s-education-overview; accessed on 6th November 2020.

UNITED STATES HISTORY \& BACKGROUND. Online source. Retrieved from: https://education.stateuniversity.com/pages/1627/United-States-HISTORY-BACKGROUND.html ; accessed on $7^{\text {th }}$ November 2020.

US DEPARTMENT OF EDUCATION (2020) The Federal Role in Education. Online source. Retrieved from. https://www2.ed.gov/about/overview/fed/role.html ; accessed on September $20^{\text {th }} 2020$.

US HIGHSCHOOL GRADUATION RATES. Online source. Retrieved from: https:// www.edweek.org/media/34gradrate-c1.pdf; accessed on October $15^{\text {th }} 2020$.

US HISTORY a. Online source. Retrieved from: https://www.ushistory.org/us/12d.asp; accessed on September $24^{\text {th }} 2020$.

US HISTORY b. Online source. Retrieved from: https://www.ushistory.org/us/index. asp; accessed on September $20^{\text {th }} 2020$.

WIKIPEDIA. Online source. https://en.wikipedia.org/wiki/2019_college_admissions bribery_scandal; accessed on September $20^{\text {th }} 2020$. 
POVZETEK

\section{ODNOS DO FORMALNEGA IZOBRAŽEVANJA V KONTEKSTU NEDAVNEGA ŠKAN- DALA Z VISOKOŠOLSKIMI ŠOLNINAMI V ZDA}

Članek se osredotoča predvsem na sodobne izzive dostopnosti akreditiranih programov izobraževalnih institucij v kontekstu Združenih držav Amerike in v manjšem obsegu tudi Slovenije. V večjem delu se navezuje na nedavni škandal v zvezi z univerzitetnimi šolninami in ga interpretira $\mathrm{z}$ vidika zgodovinskih okvirov ameriškega izobraževalnega sistema in v povezavi s tradicionalnimi družbenimi praksami. V uvodnem delu se posveti kratkemu pregledu razvoja ameriškega (visokošolskega) izobraževalnega sistema, katerega začetki segajo daleč nazaj v prvo polovico sedemnajstega stoletja, ko se je pojem formalnega izobraževanja šele razvijal. $Z$ opisom izbranih aspektov in zgodovinskih trendov ameriškega šolstva na različnih izobraževalnih stopnjah razkriva pričakovanja ter odnos do pridobivanja formalne izobrazbe $v$ preteklosti. $Z$ navedbo nekaterih pomembnih sprememb v izobraževalnem sistemu na državni ravni in opisom novejših pristopov $\mathrm{k}$ izobraževanju v ameriškem kulturnem prostoru izriše ozadje odnosa do formalnega izobraževanja v sodobni ameriški družbi. S pregledom statističnih podatkov v zvezi z vpisom na srednješolske in visokošolske programe kaže vpogled $v$ naraščajoči trend vpisa $v$ formalno akreditirane izobraževalne ustanove tako v Združenih državah Amerike kot v Sloveniji. Prikazani izsledki raziskave pričajo $\mathrm{v}$ prid primerljivi dostopnosti formalnega izobraževanja $\mathrm{v}$ obeh omenjenih državah, ZDA in Sloveniji, kar je pomemben podatek, predvsem v kontekstu omenjenega škandala, ki na prvi pogled botruje vtisu, da so formalne izobraževalne institucije podvržene taktirki vplivnih posameznikov. S tem izsledki raziskave in zaključki dodatno osvetlijo pomen dostopnosti izobraževanja kot sistema, ki v sodobnih razvitih družbah zagotavlja enake možnosti vsakemu posamezniku, ne glede na njegov družbeni status ali finančno (pre)moč. Kot tak se izobraževalni sistem in pridobljeno znanje izkazujeta kot pomembna dejavnika izravnavanja družbenih neenakosti.

Ključne besede: dostopnost, družbena neenakost, odnos, visoko šolstvo, zgodovinski pregled.

\section{ABSTRACT}

The following paper discusses contemporary challenges of providing access to formally accredited higher education programs in the United States of America, and on a smaller scale also in Slovenia. It interprets the recent college admissions scandal within the historical framework of American educational policies, paired with its traditional social practices. In the initial sections, the paper provides a brief historical overview of the development of American (higher) education, the beginnings of which date as far back as the early $17^{\text {th }}$ century. Back then, the very concept of formal and publicly accessible education was in its developmental stages. By focusing on a selection of historical aspects and educational trends within the American national context, the paper unveils 
the related expectations and attitudes toward acquiring formal education in the past. It lists a number of historically relevant changes, which have been implemented over the past century within the American educational system at state and federal levels. The latter have contributed to the development of contemporary approaches to education and have affected recent attitudes toward formal education in American society. The paper includes statistical data on enrolments and graduation rates in institutions of higher education in the United States and Slovenia, which offers an insight into the rising enrolment and graduation trends, and relates the figures to the importance of accessibility of education as an equalizer that should provide equality of opportunity for all, irrespective of social background or economic power. The accrued data and related research results support a favorable trend in accessibility of formal education in both countries, the US and Slovenia. This is an important finding, particularly in the context of the college tuition scandal, as it might at first sight create the impression that some of the highly valued and formally accredited institutions of higher education were subject to the influence of a powerful elite. The research results therefore support the trend of the educational system and the accrued knowledge assuming the role of the equalizer in leveling out certain aspects of social inequality.

Keywords: accessibility, attitudes, equalizer, higher education, historical overview 